\title{
Bevry om vry te wees
}

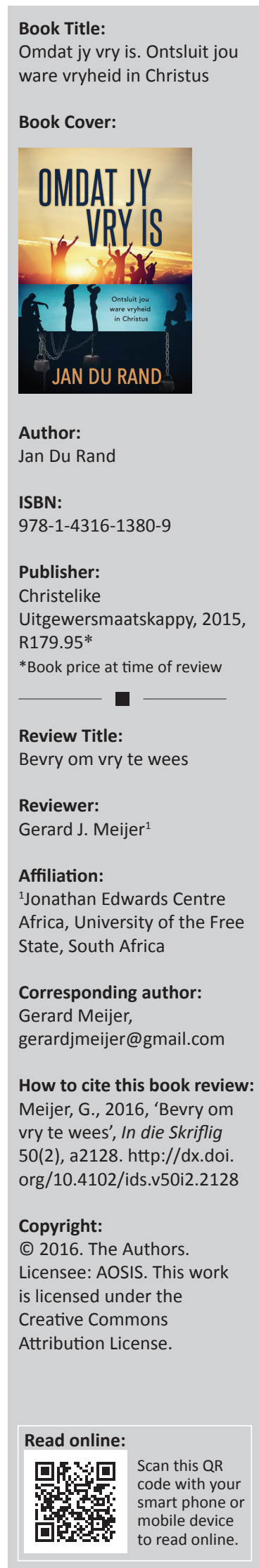

Wat is dit wat jou soos ' $n$ GPS op jou lewenspad op koers hou? Dit is die vraag waarmee prof. Jan du Rand in Omdat jy vry is besig is. Dit is vir elke mens 'n uiters aktuele vraag. Die skrywer noem in sy voorwoord dat hy veral drie groepe lesers in gedagte het: Voltydse gelowiges wat nog die kerk kies en by die lees van die boek hulle vryheid in Christus herwaardeer, buitemuurse gelowiges wat die rug op die kerk gedraai het, maar beslis nog glo, en ongelowiges wat dalk swaar belas is deur allerlei ander lojaliteite. Hulle kan dalk net getref word deur die ware vryheid in Christus.

Die boek is inderdaad vir jonk en oud bedoel, vir soeker en vinder, vir twyfelaar en bewonderaar.

Die kern van die saak waarby uitgekom word, is dat 'n mens slegs vry kan wees as jy behoorlik weet wie jy is, jouself kan losmaak van allerhande kragte en magte wat jou negatief beïnvloed, weet wat ware vryheid is, en jouself aan die ware vryheid vasbind.

In die eerste van vyf hoofstukke beskryf Du Rand hoe belangrik dit is dat jy 'n deeglike kennis van jouself moet hê. Sonder selfkennis sal jy nooit bevry kan word van wat jou in hierdie gebroke lewe aan allerhande negatiewe dinge bind nie. Selfkennis is in baie opsigte ontnugterend, maar dit werk helend.

In die tweede hoofstuk word ingegaan op konkrete sake waarvan 'n mens bevry moet word. Maak jou los van sonde en sondegebondenheid. Los van jou ego-self wat heeltyd onkant neig. Los van die greep van die Bose en Satan op jou. Los van geskinder en om ander so maklik te oordeel. Los van oordrewe gehegdheid aan aardse skatte en status van liggaamlikheid en die uiterlike. Maak jou los van baie ander dinge wat jou onnodig, verkeerdelik vashou.

Hoofstukke drie en vier vorm die kern van die boek. Hoe lyk ware vryheid regtig? Wat is dit om vry te wees? In ons wêreld is daar 'n soeke en 'n gejaag na vryheid, maar dit word steeds deur soveel mense ontbeer. Ware vryheid kan slegs in Christus gevind word. Hy alleen bevry ons om vry te wees. Vir al drie teikengroepe wat die skrywer in die oog het, sal die vryheid in Christus die hoogtepunt wees. Of 'n mens 'n kerkvaste gelowige, 'n buitekerklike gelowige of 'n ongelowige is: by Christus alleen is vryheid te soek en te vind.

Die boek sluit af met 'n uitgebreide vyfde hoofstuk oor wat die vryheid in Christus prakties inhou. Christelike vryheid is 'n nuwe gebondenheid. Jy word vasgebind aan die Drie-enige God. Bevry-wees in Christus beteken dissipelskap en navolging van Christus. Jy is verbind aan ' $n$ gemeenskap van gelowiges, vrede en gemoedsrus. Vry-wees het alles te doen met opregte vergewe van mekaar sonder om te verwyt, die uitreik na verwondes en armes, die innerlike aanvaarding van siekte en lyding. Om deur Christus bevry te wees gee die regte perspektief op sending en evangelisasie, ander godsdienste, wetenskap en tegnologie, postmodernisme en ekologiese vraagstukke. In 33 kort paragrawe hanteer die skrywer 'n magdom uiteenlopende onderwerpe wat vryheid in Christus alles inhou.

Die waarde van die boek lê daarin dat dit toepaslik is en konkreet is. Teologiese begrippe, vakterme en woorde uit die Hebreeus en Grieks word in verstaanbare Afrikaans verduidelik. Dit maak die werk maklik volgbaar, ook vir die nie-teoloog.

Die boek word afgerond met 'n sinvolle woordelys. In aansluiting by die uitgebreide inhoudsopgawe, help die woordelys die leser om begrippe en sake waarvoor gesoek word maklik te vind.

Die boek is uitgesproke reformatories. Sake soos uitverkiesing en erfsonde word op ' $n$ tradisioneel reformatoriese (gereformeerde) wyse verklaar en verwerk. Tog word daar nie met die gereformeerde belydenisskrifte gewerk nie. Dit mag dalk die rede wees waarom daar 'n eienaardige onderskeiding 
gemaak word tussen die natuurlike en eiegeregtige ego-self (in Bybel- en belydenistaal 'ou mens') en die beter gees-self as deel van jouself (bl. 31). Die klem op die vrye wil van die mens sluit hierby aan (bl. 97). Ook die term Jesus-spiritualiteit is vreemd aan die gereformeerde belydenis.

In geheel gesien is die boek egter dubbel en dwars die moeite werd om gelees en herlees te word. Dit is geen boek om sommer-so een agtermiddag deur te blaai nie. Elke hoofstuk en paragraaf moet oordink en jou eie gemaak word. Dan put jy waarde daaruit.

Die prys is billik. Die boek verdien myns insiens 'n beter kwaliteit papier om op gedruk te word. As glanstydskrifte met soveel sorg uitgegee kan word, soveel te meer 'n publikasie met hierdie inhoud. 